\title{
Kajian Neurosis Tokoh dalam Novel Koma (Cinta Tanpa Titik) Karya Mercy Sitanggang
}

\author{
RINI ARYANI \\ Email: rinisupri02@gmail.com \\ Guru SMP Negeri 2 Muara Padang Banyuasin
}

\begin{abstract}
Abstrak-Tujuan penelitian ini untuk mengetahui dan mendeskripsikan neurosis tokoh yang terdapat dalam novel Koma (Cinta Tanpa Titik) karya Mercy Sitanggang. Penelitian ini menggunakan metode deskriptif. Sumber data yang digunakan adalah novel Koma (Cinta Tanpa Titik) karya Mercy Sitanggang, yang berjumlah 256 halaman, menggunakan pendekatan psikologis. Teknik pengumpulan data menggunakan teknik dokumentasi sedangkan teknik analisis data menggunakan teknik analisis konten. Berdasarkan hasil penelitian dan pembahasan diketahui bahwa Novel Koma (Cinta Tanpa Titik) karya Mercy Sitanggang merupakan novel yang mencerminkan gejala kejiwaan, khusunya neurosis yang tercermin melalui ucapan, tindakan, dan perilaku tokoh-tokohnya. Secara Secara keseluruhan jumlah tokoh yang terdapat dalam novel Koma (Cinta Tanpa Titik) karya Mercy Sitanggang berjumlah 10 tokoh yang terdiri dari satu tokoh utama, yakni Bianca dan 9 tokoh pembantu, yakni: Vennya, Alex, Wayan, Mama Bianca, Jojo, Ramses, Irwanda, Carol, Ida. Dari sepuluh tokoh tersebut, setelah dianalisis hanya ditemukan tiga tokoh yang mengalami neurosis, yakni tokoh Bianca, Mama Bianca, dan Wayan.
\end{abstract}

Kata Kunci: Neurosis Tokoh, sastra

Abstract- The purpose of this study was to determine and describe the neuroses of the characters contained in the novel Koma (Cinta Tanpa Titik) by Mercy Sitanggang. This research uses a descriptive method. The data source used is the novel Koma (Cinta Tanpa Titik) by Mercy Sitanggang, which amounts to 256 pages, using a psychological approach. Data collection techniques using documentation techniques while data analysis techniques use content analysis techniques. Based on the results of research and discussion, it is known that the Novel Koma (Cinta Tanpa Titik) by Mercy Sitanggang is a novel that reflects psychological symptoms, especially neuroses which are reflected through the speech, actions, and behavior of the characters. Overall, the total number of characters contained in the novel Koma (Cinta Tanpa Titik) by Mercy Sitanggang amounted to 10 characters consisting of one main character, namely Bianca and 9 supporting characters, namely: Vennya, Alex, Wayan, Mama Bianca, Jojo, Ramses, Irwanda, Carol, Ida. Of the ten figures, after being analyzed only found three figures who experienced neurosis, namely Bianca, Mama Bianca, and Wayan.

\section{Keywords: Figure Neurosis, literary}

\section{PENDAHULUAN}

Karya sastra ialah fenomena unik. la juga fenomena organik. Di dalamnya penuh serangkaian makna dan fungsi. Makna dan fungsi ini sering kabur dan tak jelas. Oleh karena, karya sastra memang syarat imajinasi. Itulah sebabnya, peneliti sastra memiliki tugas untuk mengungkap kekaburan itu menjadi jelas berdasarkan teori yang digunakan (Endraswara, 2008:7).

Menurut Endraswara (2008:96), kajian psikologi sastra disamping meneliti perwatakan tokoh secara psikologis juga aspek-aspek pemikiran dan perasaan pengarang ketika menciptakan karya tersebut. Seberapa jauh pengarang mampu menggambarkan perwatakan tokoh sehingga karya menjadi 
semakin hidup. Sentuhan-sentuhan emosi melalui dialog atau pun pemilihan kata, sebenarnnya merupakan gambaran kekalutan dan kejernihan batin pencipta. Kejujuran itulah yang akan menyebabkan orisinalitas karya. Psikologi sastra adalah kajian sastra yang memandang karya sebagai aktivitas kejiwaan. Pengarang akan menggunakan cipta, rasa, dan karya dalam berkarya.

Menurut Sarwono (2012:241), dalam psikologi dikenal perilaku-perilaku yang menyimpang dari pada tingkah laku normal. Penyimpangan dari perilaku yang normal sebagai gejala dari ganguan mental. Penyimpangan perilaku ini dapat disebabkan oleh adanya kelainan psikis pada orang yang bersangkutan, tetapi bisa juga disebabkan karena adanya sumber stres yang datang dari luar, atau perubahan sosial yang mengubah kriteria normal dan tidak normal. Kelainan psikis dapat dikelompokan ke dalam beberapa jenis sebagai berikut, (1) keterbelakangan mental; (2) kelainan seksual;

(3) psikoneurosis; (4) psikosis; (5) psikopat (Ahmadi, 2009:196).

Salah satu pembangun karya satra fiksi (termasuk novel) adalah unsur psikologis (kejiwaan). Proses kejiwaaan dalam diri manusia yang tergambar melalui sikap dan perilaku tokoh-tokoh cerita dalam suatu karya sastra terdiri dari bermacam-macam jenis, salah satunya adalah neurosis. Hal ini sesuai dengan pendapat Ratna (2012:62) yang mengemukakan bahwa karya sastra dianggap sebagai hasil aktivitas peneliti yang sering dikaitkan dengan kejiwaan, seperti: obsesi, kontemplasi, kompensasi, sublimasi bahkan sebagai neurosis. Oleh karena itu, karya sastra disebut sebagai salah satu gejala (penyakit) kejiwaan yang disebabkan konflik batin akibat kebutuhan yang kurang terpenuhi.

Unsur kejiwaan dalam suatu karya sastra itu sendiri dapat dikaji melalui tokoh cerita yang terdapat didalamnya. Istilah tokoh menunjukkan pada pelaku dalam cerita. Pelaku cerita yang ditampilkan sastrawan merupakan seorang tokoh yang hidup secara wajar sebagaimana kehidupan manusia yang mempunyai pikiran dan perasaan. Oleh sebab itu, dalam sebuah karya sastra seorang sastrawan selalu mengaitkan ceritanya dengan manusia yang berinteraksi terhadap lingkungannya. Untuk itu pelaku cerita sering dikaitkan dengan kenyataan manusia seharihari.

Perilaku yang tampak dalam kehidupan sehari-hari bagi setiap orang belum sepenuhnya menggambarkan diri mereka masing-masing. Apa yang diperlihatkan belum tentu sama dengan apa yang sesungguhnya terjadi di dalam dirinya karena manusia seringkali berusaha menutupi. Kejujuran, kecintaan, kemunafikan, dan lain-lain berada di dalam batin masingmasing yang kadang-kadang terlihat gejalanya dari luar dan kadang-kadang tidak (Semi, 1993:78). Jadi karya sastra (novel) dapat dijadikan media untuk mengenal dan memahami manusia dan kehidupannya.

Adanya kenyataan bahwa suatu karya sastra, termasuk novel tidak dapat dipisahkan 
dari unsur kejiwaan yang tercermin melalui sikap dan perilaku tokoh inilah yang menarik minat peneliti untuk mengadakan penelitian tentang kajian neurosis tokoh dalam novel Koma (Cinta Tanpa Titik) karya Mercy Sitanggang.

Dari hal itulah penulis akan mengungkapkan kajian neurosis tokoh dalam novel Koma (Cinta Tanpa Titik) karya Mercy Sitanggang. Masalah yang akan dibahas dalam penelitian ini adalah bagaimanakah kajian neurosis tokoh dalam novel Koma (Cinta Tanpa Titik) karya Mercy Sitanggang? Tujuan penelitian ini adalah mengetahui dan mendeskripsikan neurosis tokoh yang terdapat dalam novel Koma (Cinta Tanpa Titik) karya Mercy Sitanggang. Hasil penelitian ini diharapkan dapat bermanfaat bagi guru dan siswa, penikmat sastra, bagi pembaca, dan bagi peneliti lain.

1) Bagi guru dan siswa, hasil penelitian ini diharapkan dapat menjadi bahan pembelajaran Sastra Indonesia dalam hal analisis sebuah karya sastra seperti novel.

2) Bagi penikmat sastra, hasil penelitian ini diharapkan dapat menjadi bacaan Sastra Indonesia dalam analisis sebuah novel.

3) Bagi pembaca, hasil penelitian ini diharapkan dapat membantu pembaca khususnya untuk mengetahui dan memahami tentang neurosis tokoh.

4) Bagi peneliti lain, diharapkan sebagai sumber acuan agar dapat mengadakan penelitian lebih lanjut mengenai kajian neurosis tokoh dalam novel.

\section{Pengertian Neurosis}

Istilah neurosis diciptakan oleh seorang pakar dari Inggris William Cullen. Semula ia mengira bahwa neurosis sekedar gangguan sistem syaraf. Jadi, mula-mula gangguan syaraf dipandang sebagai sumber tingkah laku neurotik. Dua abad kemudian, Sigmund Freud mengajukan pendapat bahwa sumber neurosis adalah konflik batin (intrapychic conflict) yang terus-menerus sebagai bentuk ketidakmampuan menyesuaikan diri yang sifatnya serius terhadap tuntutan dan kondisi lingkungan yang mengakibatkan ketidakmampuan tertentu. Sumber gangguan/ kekacauannya bisa bersifat psikogenis atau organis, mencakup kasus-kasus reaksi psikopatis, dan reaksi-reaksi neurotis yang gawat. Sebaliknya, kaum behavioris berpendapat bahwa sumber neurosis adalah cara belajar yang keliru (faulty learning) dalam menghindari kecemasan (Wiramihardja, 2007:67).

Menurut Kartono (2009:97), "Neurosis adalah sekelompok reaksi psikis ditandai secara khas oleh unsur kecemasan, yang tidak sadar diekspresikan dengan menggunakan mekanisme pertahanan diri (deference mechanism)." Selanjutnya, Supratiknya (dikutip Sobur, 2013:344), "Neurosis adalah gaya hidup maladaptif yang berupa tingkah laku yang bersifat defensif dengan tujuan menghindari atau mengurangi rasa cemas."

Selain itu, menurut Wiramihardja (2007:67), "Neurosis adalah sebagian dari gangguan yang didasari oleh kecemasan, gangguan ini umumnya lebih didasari oleh kepribadian atau kondisi psikologi yang lemah, 
kurang mantap atau terlalu kaku dalam menghadapi berbagai permasalahan.

Menurut Ahmadi (2009:204), neurosis pada hakikatnya bukan suatu penyakit. Orangorang menderita neurosis pada umumnya dapat disebut sebagai orang normal karena masih dapat bergaul, bekerja, belajar, dan sebagainya seperti orang lainnya hanya saja yang diderita oleh orang neurosis adalah ketegangan pribadi yang terus-menerus akibat adanya konflikkonflik dalam diri orang tersebut yang juga terus-menerus. Orang tersebut tidak dapat mengatasi konflik-konfliknya sehingga tegangan tidak kunjung reda, dan akhirnya menjadi neurosis.

Berdasarkan pendapat di atas, dapat disimpulkan bahwa neurosis adalah gangguan yang didasari oleh unsur kecemasan atau psikologis yang lemah sehingga selalu bertingkah laku mempertahankan diri dari gangguan-gangguan dengan tujuan untuk menghindari atau mengurangi rasa cemas.

\section{Bentuk-bentuk Neurosis}

Menurut Sobur (2013:344-348), "Pola atau bentuk neurosis adalah (1) gangguan kecemasan yang ekstrim (histeria), (2) gangguan fobia, dan (3) gangguan kompulsifobsesif." Sementara itu, menurut Kartono (2009:132-184), "Terdapat empat macam (1) hysteria, (2) fobia, (3) gangguan kompulsifobsesif, dan (4) tekanan pos atau trauma."

Berdasarkan pendapat di atas, dapat disimpulkan bahwa bentuk-bentuk neurosis terdiri atas: (1) gangguan kecemasan yang ekstrim (histeria), (2) gangguan fobia, dan (3) gangguan kompulsif-obsesif, dan (4) tekanan pos atau trauma."

\section{Gangguan Kecemasan yang Ekstrim (Hysteria)}

Menurut Kartono (2009:99), " Histeria ialah satu neurosa yang kompleks dalam beberapa bentuk penampilannya, dengan ciriciri khas ketidakstabilan emosional, represi, dissosiasi, dan sugestibilitasi. Selanjutnya, menurut Ahmadi (2009:207), "Histeria adalah penderita psikoneurosis jenis ini secara tidak sadar meniadakan fungsi salah satu anggota tubuhnya sendiri, sehingga sekalipun secara organis tidak ditemui adanya kelainan, anggota tubuh itu tidak dapat menjalankan fungsinya."

Berdasarkan pendapat di atas, dapat disimpulkan bahwa histeria adalah gangguan psikologis dengan ciri emosionalitas ektrim yang tidak terkendali yang disebabkan oleh macammacam konflik internal, masalah keluarga dan penyesuaian diri yang slah yang dialami dalam kehidupan.

\section{Gangguan Fobia}

Menurut Supraktiknya (dalam Sobur 2013:347), "Fobia adalah perasaan takut yang bersifat menetap terhadap objek atau situasi tertentu yang sesungguhnya tidak menimbulkan ancaman nyata bagi yang bersangkutan atau yang bahayanya terlalu dibesar-besarkan. Fobia adalah takut yang irasional pada suatu objek atau situasi tertentu (Sarwono 2012:250). 
Berdasarkan pendapat di atas, dapat disimpulkan bahwa fobia dalah perasaan cemas atau ketakutan terhadap situasi tertentu yang sesungguhnya tidak menimbulkan ancaman nyata bagi orang yang bersangkutan.

\section{Gangguan Obsesif-Kompulsif}

Menurut Ahmadi (2009:207) " ObsesifKompulsif adalah adanya pikiran dan dorongan tertentu secara terus-menerus. Orang yang bersangkutan tahu bahwa pikiran dan dorongan itu tidak benar dan tidak masuk akal, tetapi ia tidak mau melepaskannya.

Berdasarkan pendapat di atas, dapat disimpulkan bahwa obsesif-kompulsif adalah suatu pikiran yang muncul secara terusmenerus yang dapat mengakibatkan terjadinya suatu tindakan yang tidak penting secara berulang-ulang tanpa bisa dikendalikan atau dicegah.

\section{Tekanan Pos atau Trauma}

Menurut Kartono (2009:183), "Tekanan pos atau trauma merupakan kecemasan yang terjadi setelah seorang mengalami sesuatu kejadian atau peritiwa yang traumatik. Trauma dapat menyebabkan individu menarik diri dari interaksi sosial." Selanjutnya, menurut Wiramihardja (2007:21), "Trauma psikis yaitu untuk menerangkan setiap pengalaman yang tidak menyenangkan, yang memberikan pengaruh terjadinya pemahaman negatif yang serius yang kemudian dapat menimbulkan cedera psikologis pada individu."
Berdasarkan pendapat di atas, dapat disimpulkan bahwa tekanan pos atau trauma merupakan gangguan kecemasan yang terjadi setelah seseorang mengalami kejadian yang sulit dilupakan dan muncul setelah beberapa tahun kejadian yang menimbulkan cedera psikologis pada individu.

Keempat pola atau bentuk neurosis inilah yang akan peneliti jadikan landasan dalam melakukan kajian neurosis tokoh dalam novel Koma (Cinta Tanpa Titik) karya Mercy Sitanggang.

\section{Pengertian Tokoh}

Nurgiyantoro mengemukakan bahwa istilah tokoh menunjuk pada orangnya, pelaku cerita. Selanjutnya menurut Aminuddin (2009:79), "Tokoh adalah pelaku yang mengemban peristiwa dalam cerita fiksi sehingga peristiwa itu mampu menjalin suatu cerita."

Berdasarkan pendapat di atas, dapat disimpulkan bahwa tokoh adalah pelaku cerita yang mengemban suatu cerita dalam cerita sehingga peristiwa terjalin menjadi suatu cerita yang bersesuaian.

\section{Macam-Macam Tokoh}

Menurut Aminuddin (2009:79-80), "Para tokoh yang terdapat dalaam suatu cerita memiliki peranan yang berbeda-beda. Seorang tokoh yang memiliki peranan penting dalam suatu cerita disebut dengan tokoh inti atau tokoh utama. Sedangkan tokoh yang memiliki peranan tidak penting karena pemunculannya hanya 
melengkapi, melayani, mendukung pelaku utama disebut tokoh tambahan atau tokoh pembantu."

Menurut Nurgiyantoro (2013:260) mengemukakan, "Dilihat dari fungsi penampilan tokoh dapat dibedakan menjadi tokoh protagonis dan tokoh antagonis. Tokoh protagonis adalah tokoh yang dikagumi yang menampilkan sesuatu sesuai dengan pandangan seseorang, harapan-harapan seseorang sebagai pembaca, sedangkan tokoh antagonis adalah tokoh yang menyebabkan terjadinya konflik." Selanjutnya

Berdasarkan pendapat di atas, dapat disimpulkan bahwa macam-macam tokoh adalah sebagai berikut.

1) Tokoh utama atau tokoh inti yakni tokoh yang memiliki peranan penting dalam suatu cerita atau menentukan jalan cerita dan ditampilkan terus-menerus.

2) Tokoh pembantu atau tokoh tambahan yakni tokoh yang melengkapi, melayani, dan mendukung pelaku utama yang hanya dimunculkan sesekali atau beberapa kali dalam cerita.

3) Tokoh protagonis adalah tokoh yang memiliki watak yang baik sehingga disenangi pembaca.

4) Tokoh antagonis adalah tokoh yang tidak disenangi pembaca karena memiliki watak yang tidak sesuai dengan apa yang didambakan oleh pembaca.

\section{Pengertian Novel}

Nurgiyantoro (2013:12), "Novel adalah sebuah karya prosa fiksi yang panjangnya cukupan, tidak terlalu panjang, namun juga tidak terlalu pendek." Menurut Kosasih (2008:54), "Novel adalah karya imajinatif yang mengisahkan sisi utuh problematika kehidupan seseorang atau beberapa orang tokoh." Selanjutnya menurut

Berdasarkan pendapat di atas, dapat disimpulkan bahwa novel adalah suatu cerita prosa fiksi sederhana yang menceritakan atau melukiskan para tokoh, gerak, kejadian, serta adegan suatu kejadian dalam kehidupan seseorang yang menyebabkan perubahan sikap hidup yang nyata dalam suatu alur.

\section{Psikologi Sastra}

Psikologi sastra adalah kajian sastra yang memandang karya sebagai aktivitas kejiwaan. Pengarang akan menggunakan cipta, rasa, dan karya dalam berkarya. Begitu pula pembaca, dalam menanggapi karya juga tak lepas dari kejiwaan masing-masing. Bahkan, sebagaimana sosiologi refleksi, psikologi sastra pun mengenal karya sastra sebagai pantulan kejiwaan. Pengarang akan menangkap gejala jiwa kemudian diolah ke dalam teks dan dilengkapi dengan kejiwaannya (Endraswara, 2008: 96).

\section{Kajian Terdahulu yang Relevan}

Penelitian mengenai kajian neurosis tokoh dalam karya sastra novel yang pernah dilakukan oleh Winarni, mahasiswa Program Studi Pendidikan Bahasa dan Sastra Indonesia, Jurusan Pendidikan Bahasa dan Seni, Fakultas Keguruan dan IImu Pendidikan Universitas 
Persatuan Guru Republik Indonesia Palembang tahun 2009 dengan judul skripsi, "Neurosis Tokoh Dalam Novel Beauty For Killing Karya Fradhyt Fahrenheit: Suatu Kajian Psikologi Sastra."

Hasil penelitian menunjukkan bahwa bentuk atau gejala-gejala neurosis yang terjadi dalam novel Beauty For Killing karya Fradhyt Fahrenheit adalah histeria, fobia, obsesifkompulsif dan tekanan post-trauma. Dari penelitian yang dilakukan Winarni tersebut, terdapat persamaan dengan penelitian yang peneliti lakukan adalah sama-sama meneliti dan mengkaji neurosis tokoh yang terdapat dalam sebuah karya sastra yang berbentuk novel, sedangkan perbedaannya terletak pada sumber data yang dianalisis. Sumber data yang dikaji oleh Winarni adalah novel Beauty For Killing karya Fradhyt Fahrenheit sedangkan peneliti melakukan kajian terhadap novel Koma (Cinta Tanpa Titik) karya Mercy Sitanggang.

\section{METODELOGI PENELITIAN}

\section{Kajian neurosis tokoh dalam novel Koma (Cinta Tanpa Titik) karya Mercy} Sitanggang adalah melakukan telaah atau kajian mengenai bentuk-bentuk neurosis tokoh atau pelaku cerita yang terdapat dalam novel Koma (Cinta Tanpa Titik) karya Mercy Sitanggang yang terdiri atas : (1) gangguan kecemasan yang ekstrim (histeria), (2) gangguan fobia, dan (3) gangguan kompulsif-obsesif, dan (4) tekanan pos atau trauma.

\section{Sumber Data}

Adapun sumber data dari penelitian ini adalah novel Koma (Cinta Tanpa Titik) karya Mecy Sitanggang, diterbitkan oleh Story House, Jakarta pada tahun 2013 dengan jumlah halaman 256 halaman dan berukuran lebar 13 cm dan panjang $19 \mathrm{~cm}$.

\section{Metode Penelitian}

Adapun metode yang digunakan dalam penelitian ini adalah metode deskriptif. Metode deskripstif ini peneliti gunakan untuk menganalisis, memahami, dan menggambarkan neurosis tokoh yang terdiri atas: (1) gangguan kecemasan yang ekstrim (histeria); (2) gangguan fobia; (3) gangguan kompulsifobsesif; dan (4) tekanan pos atau trauma dalam novel Koma (Cinta Tanpa Titik) karya Mercy Sitanggang.

\section{Pendekatan Penelitian}

Adapun pendekatan yang digunakan dalam penelitian ini adalah pendekatan psikologis. Melalui pendekatan ini penulis menganlisis pemikiran dan unsur kejiwaan yang digambarkan pengarang, khususnya bentukkbentuk neurosis tokoh yang terdapat dalamm novel Koma (Cinta Tanpa Titik) karya Mercy Sitanggang, yakni dengan menganalisis ucapan, tindakan, dan perilaku tokoh-tokoh baik itu tokoh utama maupun tokoh tambahan yang menunjukkan adanya bentuk-bentuk neurosis yang terdiri dari gangguan kecemasan yang ekstrim (histeria), gangguan fobia, gangguan obsesif-kompulsif, dan tekanan pos atau trauma. 


\section{Teknik Pengumpulan Data}

Teknik yang digunakan untuk mengumpulkan data dalam penelitian ini adalah teknik dokumentasi. Dalam penelitian ini dapat diketahui bahwa peneliti melakukan pencarian data melalui buku yaitu novel Koma (Cinta Tanpa Titik) karya Mercy Sitanggang untuk dijadikan sebagai dokumentasi yang harus diteliti dan dianalisis sehingga data-data yang diperlukan oleh peneliti dapat diperoleh secara lengkap.

\section{Teknik Analisis Data}

Teknik analisis data yang digunakan dalam penelitian ini adalah teknik analisis konten. Menurut Endraswara (2008:161), analisis konten adalah strategi untuk menangkap pesan karya sastra.

Adapun langkah-langkah yang dilakukan adalah sebagai berikut.

1) Membaca novel Koma (Cinta Tanpa Titik) karya Mercy Sitanggang secara teliti dan seksama untuk dapat memahami maksud ceritannya.

2) Membuat sinopsis cerita.

3) Menentukan tokoh-tokoh yang terdapat dalam novel Koma (Cinta Tanpa Titik) karya Mercy Sitanggang.

4) Menganalisis cerita untuk mengetahui neurosis tokoh yang terdapat dalam novel Koma (Cinta Tanpa Titik) karya Mercy Sitanggang.

5) Mengklasifikasikan neurosis tokoh yang terdapat dalamm novel Koma (Cinta Tanpa Titik) karya Mercy Sitanggang yang disertai dengan kutipan-kutipan teks.
6) Mendeskripsikan neurosis tokoh yang terdapat dalam Koma (Cinta Tanpa Titik) karya Mercy Sitanggang.

7) Membuat pembahasan.

8) Membuat kesimpulan.

\section{HASIL PENELITIAN DAN PEMBAHASAN}

Lima tahun menjalin hubungan cinta tentu bukan waktu yang sebentar. Selama itu pula Bianca menjaga kesetiaannya pada Alex. Namun sayangnya, mereka malah bertengkar hebat pada hari ulang tahun Alex. Alex merasa hubungan mereka sudah tidak sehat. Perhatian Bianca yang selalu membuat Alex luruh dan bangga menjadi kekasihnya. Alex cemburu dengan tulisan dan laptopnya yang lebih sering dikencani dari pada dirinya. Dan setelah pertengkaran itu, semua berubah. Alex tak pernah lagi menghubungi Bianca.

Beberapa hari kemudian tepat di hari jadi mereka yang kelima tahun, Bianca berinisiatif menemui Alex di rumahnya. Bianca berharap Alex akan memberikan cincin sebagai kado ulang tahun hari jadi mereka. Pelan-pelan Bianca membuka pintu dan mendekati ranjang Alex. Disinilah Bianca menyadari bahwa kesetiannya telah ternodai. Sosok laki-laki yang Biancaa cintai itu sedang tertidur di atas ranjang, bersama dengan seorang perempuan lain. Saling berpelukan. Bianca memutuskan pulang dengan rasa sakit yang begitu mendalam bagai tertusuk beribu pisau. Akhirnya Bian mendapatkan jawaban dari kegelisahannya selama ini. Itu memang tanda dari Tuhan. Kalau Alex bukan lelaki yang baik. 
Sakit hati Bianca pada Alex memicu dendam dan menyulut api kebencian pada semua lelaki. Menurut Bianca semua laki-laki sama seperti Alex. Oleh karena itu, setiap bersama laki-laki Bianca tidak pernah pakai hati. Bianca kemudian menjadi matre semenjak hatinya sakit dan patah. Kebahagiaannya berpaling pada laki-laki dan isi dompetnya. Terlalu besar rasa sakit Bianca sehingga tidak bisa membuka hati untuk laki-laki lain.

Bianca menemukan semangat barunya ketika bertemu dengan lelaki sederhana dengan wajah serupa malaikat. Bianca bertemu dengan lelaki yang memiliki senyum indah itu di toko buku. Bianca jatuh cinta lagi. Wayan adalah Sosok lelaki berwajah malaikat itu. Wayanlah yang membuat Bianca meninggalkan koma, berlari mencari titik. Dengan seperti itu, Bianca bisa melupakan Alex yang mulai hadir kembali dikehidupan Bianca setelah bercerai dengan perempuan yang dinikahinya. Saat ini, Bianca tidak menginginkan Alex kembali. Bianca hanya butuh wajah malaikat itu untuk merubah dirinya, merubah hidupnya. Kehadiran Wayan menyadarkan Bianca dari koma. Harapan Bianca bisa hidup bersama Wayan di masa depan, punya keluarga dan anak.

Bianca kembali diliputi kesedihan yang mendalam dengan kejujuran Vennya pada Bianca. Vennya yang seorang janda kembang itu, mengaku mencintai Bianca. Ini membuat Bianca koma kembali. I Wayan Putra Sanjaya Darsana ternyata sepupunya Vennya. Saat Bianca mulai yakin bahwa Wayan adalah cinta sejatinya, Wayan malah membuka jati dirinya sebagai pria yang sudah memiliki istri dan anak. Akhirnya Bianca memilih pergi, meski sebenarnya rumah tangga Wayan sudah retak jauh sebelum mereka berkenalan. Bertubi-tubi peristiwa pahit dalam hidup Bianca, membawa Bianca pada koma. Bianca terserang radang selaput otak. Dan sementara Bian koma, Vennya dan Wayan justru bertengkar memperebutkan Bianca. Vennya tidak rela siapapun menyakiti hati Bianca. Vennya juga mengakui kalau dirinya mencintai Bianca. Wayan kaget mendengar pengakuan Vennya. Wayan tetap berusaha meyakinkan Bianca walaupun dalam keadaan koma. Setiap hari Wayan selalu berusaha datang untuk menjenguk Bianca tanpa sepengetahuan Vennya. Novel duet Wayan dan Bianca mendapatkan juara satu. Wayan terus berdoa untuk kesembuhan Bianca. Novel hasil duet mereka Wayan berikan kepada Bianca dengan menaruhnya di samping badan Bianca. Bianca belum juga sadar dari komanya. Tetapi Bianca merasakan kedatangan Wayan yang membuat air mata Bianca menetes dari sudut matanya. Dan Bianca membiarkan jari-jarinya bergerak pelan dan menggenggam erat novel tersebut

\section{Pembahasan}

Neurosis adalah gangguan yang didasari oleh unsur kecemasan atau psikologis yang lemah sehingga selalu bertingkah laku mempertahankan diri dari gangguan-gangguan dengan tujuan untuk menghindari atau mengurangi rasa cemas. 
Berdasarkan hasil pendeskripsian dan analisis data yang telah dilakukan, diperoleh pembahasan sebagai berikut.

Novel Koma (Cinta Tanpa Titik) karya Mercy Sitanggang merupakan novel yang menceritakan tentang jalinan cinta antara seorang penulis bernama Bianca dengan Alex. Cinta pasangan ini sulit menyatu karena Bianca terlalu sibuk dengan kegiatannya menulis sehingga Alex meninggalkan Bianca dan memilih perempuan lain. Selain dengan Alex ada sosok wajah malaikat yang akhirnya menambah luka dihati Bianca yaitu I Wayan Putra Sanjaya Darsana, seorang penulis yang sekaligus kakak sepupu Vennya sahabat Bianca. Peristiwa tersebutlah yang membuat Bianca mengalami neurosis. Selain Bianca, neurosis dialami pula oleh tokoh-tokoh pembantu dalam novel ini.

Secara keseluruhan jumlah tokoh dalam novel Koma (Cinta Tanpa Titik) karya Mercy Sitanggang berjumlah 10 tokoh yang terdiri dari satu tokoh utama, yakni Bianca dan 9 tokoh pembantu, yakni: Vennya, Alex, Wayan, Mama Bianca, Jojo, Ramses, Irwanda, Carol, Ida.

Dari sepuluh tokoh tersebut, maka berdasarkan cerita yang terdapat dalam novel ini diketahui bahwa pengungkapan neurosis banyak dilakukan pengarang melalui sikap, perilaku, dan ucapan tokoh-tokohnya. Baik itu tokoh utama, yakni Bianca maupun tokoh-tokoh pembantu, yakni mama Bianca dan Wayan.

Neurosis yang terdapat dalam novel ini digambarkan pengarang dalam diri Bianca.
Sebagai tokoh utama, digambarkan pengarang sebagai tokoh yang paling banyak mengalami neurosis. Hal ini dikarenakan ucapan, tindakan, dan perilaku Bianca banyak mencerminkan neurosis, yakni gangguan kecemasan yang ekstrim atau histeria yang terjadi akibat konflik yang sedang dialaminya dengan orang lain dalam kehidupan kesadaran, gangguan fobia yang disebabkan rasa cemas dan takut meskipun kecemasan dan ketakutan tersebut tidak memiliki dasar atau alasan kuat dan bukan merupakan ancaman nyata bagi Bianca sendiri. Neurosis yang berbentuk gangguan obsesifkompulsif dalam diri Bianca adalah ketika Bianca memilih merokok untuk meredam gelisah dan tanpa ada yang bisa mencegahnya.

Bentuk neurosis lain dalam diri Bianca adalah tekanan pos atau trauma yang merupakan gangguan kecemasan yang terjadi setelah seseorang mengalami peristiwa yang sulit dilupakan dan muncul setelah waktu yang tidak terlalu lama, yakni peristiwa yang yang dialami Bianca akibat penghianatan yang dulu pernah dilakukan Alex dan selalu teringat sampai Bianca mengenal laki-laki lain, bahkan Bianca sampai menganggap semua laki-laki sama seperti Alex.

Selain Bianca, neurosis dalam novel ini digambarkan pula oleh pengarang melalui sikap, tindakan, dan ucapan tokoh-tokoh pembantunya, yakni mama Bianca. Neurosis yang dialami mama Bianca tersebut adalah gangguan kecemasan yang ekstrim atau histeria karena mama Bianca selalu merasa khawatir melihat Bianca keluar rumah sendirian. Mama 
Bianca takut terjadi apa dengan Bianca yang membuat mama Bianca selalu merasa cemas dan takut. Neurosis yang berbentuk tekanan pos atau trauma yang terjadi sejak pembunuhan suaminya itu membuat mama Bianca tidak mau berbicra kepada siapapun dan mama Bianca selalu tertawa sendiri serta memanggil nama suaminya.

Tokoh lain yang mengalami neurosis adalah Wayan. Adapun bentuk-bentuk neurosis yang terdapat pada tokoh Wayan adalah gangguan kecemasan atau histeria yang dialami Wayan ini terjadi ketika Wayan bisa bertemu dan bersentuhan kulit dengan Bianca, jatungnya berdegup kencang, Wayan shock seakan tidak percaya bisa bertemu dan bertatap muka lagi dengan Bianca, wanita yang ia cintai.

Adanya neurosis yang tergambar melalui sikap perilaku, dan ucapan tokohtokohnya, baik itu tokoh utama maupun tokoh pembantu dalam novel Koma (Cinta Tanpa Titik) karya Mercy Sitanggang ini menunjukkan bahwa neurosis yang terdapat dalam suatu karya sastra, termasuk novel merupakan unsur kejiwaan yang tidak bisa dipisahkan dari suatu karya satra yang digambarkan pengarang melalui sikap dan perilaku tokoh-tokoh cerita.

\section{SIMPULAN}

Berdasarkan hasil penelitian dan pembahasan mengenai neurosis tokoh dalam novel Koma (Cinta Tanpa Titik) karya Mercy Sitanggang diperoleh simpulan sebagai berikut. Novel Koma (Cinta Tanpa Titik) karya Mercy Sitanggang merupakan novel yang banyak mencerminkan gejala kejiwaan atau psikologis, khususnya neurosis yang tercermin melalui ucapan, tindakan, dan perilaku tokohtokohnya. Secara keseluruhan jumlah tokoh yang terdapat dalam novel Koma (Cinta Tanpa Titik) karya Mercy Sitanggang berjumlah 10 tokoh yang terdiri dari satu tokoh utama, yakni Bianca dan 9 tokoh pembantu, yakni: Vennya, Alex, Wayan, Mama Bianca, Jojo, Ramses, Irwanda, Carol, Ida. Dari sepuluh tokoh tersebut, setelah dianalisis hanya ditemukan tiga tokoh yang mengalami neurosis, yakni tokoh Bianca, Mama Bianca, dan Wayan.

Bianca digambarkan pengarang sebagai tokoh yang paling banyak mengalami neurosis baik itu gangguan kecemasan yang ektrim atau histeria, gangguan fobia, gangguan obsesif-kompulsif, maupun tekanan pos atau trauma. Selanjutnya, tokoh mama Bianca mengalami neurosis yang berbentuk gangguan kecemasan yang ekstrim atau histeria dan tekanan pos atau trauma. Terakhir, tokoh Wayan yang mengalami neurosis yakni gangguan kecemasan yang ekstrim atau histeria.

\section{DAFTAR PUSTAKA}

Ahmadi, Abu. 2009. Psikologi Umum. Jakarta: Rineka Cipta

Aminuddin. 2009. Pengantar Apresiasi Karya Sastra. Bandung: Sinar Baru Algensindo

Arikunto, Suharsimi. 2010. Prosedur Penelitian. Jakarta: Rineka Cipta

Endraswara, Suwardi. 2008. Metode Penelitian Sastra. Yogyakarta: Media Presindo 
Kartono, Kartini. 2009. Psikologi Abnormal dan Abnormalitas Seksual. Bandung: Mandar Maju

Kosasih, E. 2008. Apresiasi Sastra Indonesia. Jakarta: Nobel Edumedia

Nurgiyantoro, Burhan. 2013. Teori Pengkajian Fiksi. Yogyakarta: Gadjah Mada University Press

Ratna, Nyoman Kutha. 2012. Teori, Metode, dan Teknik Penelitian Sastra. Yogyakarta: Pustaka Pelajar

Sarwono, Sarlito W. 2012. Pengantar Psikologi Umum. Jakarta: Rajawali Pres

Semi, Atar. 1993. Metode Penelitian Sastra. Bandung: Angkasa

Sitanggang, Mercy. 2013. Koma (Cinta Tanpa Titik). Jakarta: Story House

Sobur, Alex. 2013. Psikologi Umum dalam Lintasan Sejarah. Bandung: Pustaka Setia

Wiramihardja, A Sutardjo. 2007. Pengantar Psikologi Abnormal. Bandung: Refika Aditama

Zainuddin. 1992. Materi Pokok Bahasa dan Sastra Indonesia. Jakarta: Rineka Cipta 